\title{
Immune Responses to SARS-CoV, MERS-CoV and SARS-CoV-2
}

\author{
Nihal İnandıklığlu (1) and Tunc Akkoc (1)
}

\section{Abstract}

The world has given an outbreak alarm in the last two decades, with different members of the coronavirus family infecting people at different times. The spread of the SARS-CoV2 virus, which last appeared in December 2019 in China and spread rapidly to all over the world, has led the scientific world to studies on these viruses. While scientists are trying to develop vaccines or drugs against the virus, the body's immune response to the virus is emerged the biggest guide. In this review, we aimed to provide a good view on immune strategies by comparing immunological responses to SARS-CoV-2 disease among other members of the family, SARS-CoV and MERS-CoV. In the near future, it may contribute to vaccine or drug studies to be developed on immune intervention.

\section{Keywords}

Corona virus · Covid-19 · Immune response · Mers-CoV $\cdot$ Sars-CoV

N. İnandıklıŏlu

Department of Medical Biology, Yozgat Bozok University Faculty of Medicine, Yozgat, Turkey

e-mail: nihal.inandiklioglu@yobu.edu.tr

T. Akkoc $(\bowtie)$

Department of Pediatric Allergy and Immunology,

Marmara University Faculty of Medicine, İstanbul, Turkey e-mail: tuncakkoc@marmara.edu.tr

\section{Abbreviations}

CoV

Corona viruses

+ssRNA

$\beta \mathrm{CoV}$

single-stranded positive RNA

SARS-CoV severe acute respiratory syndrome

Betacoronavirus coronavirus

MERS- Middle East respiratory syn-

$\mathrm{CoV}$ drome-coronavirus

COVID-19 Corona-virus disease 2019

ACE2 angiotensin-converting enzyme 2

CEACAM1 carcinoembryonic-antigen-related cell-adhesion molecule-1

APN aminopeptidase N

DPP-4 dipeptidyl peptidase-4

NK natural killer

MCP-1 monocyte chemoattractant protein-1

IP-10 or human interferon-inducible pro-

CXCL10 tein 10

TGF- $\beta \quad$ tumor growth factor beta

TNF- $\alpha \quad$ tumor necrosis factor alpha

MIP-l $\alpha$ macrophage inflammatory protein-1 alpha

ISGs IFN-stimulated genes

$\mathrm{S} \quad$ spike protein

$\mathrm{N} \quad$ nucleocapsid protein

CRP C-reactive protein 


\section{Introduction}

Corona viruses $(\mathrm{CoV}$; subfamily Coronavirinae, family Coronaviridae, order Nidovirales) are a quite large family of viruses containing a singlestranded positive RNA (+ssRNA) genome that typically causes cold (Woo et al. 2009). CoVs are subdivided into four genera; Alphacoronavirus, Betacoronavirus $(\beta \mathrm{CoV})$, Gammacoronavirus and Deltacoronavirus (Woo et al. 2012). A new type of $\beta \mathrm{CoV}$, which showed up in Guangdong province of China in 2002 and threatened the whole world, spread to approximately 26 countries within a year, infecting more than 8000 people with a reported mortality rate of $10 \%$ (Peiris et al. 2003). After this virus, called severe acute respiratory syndrome coronavirus (SARS-CoV), a new type of $\beta \mathrm{CoV}$ was identified in Saudi Arabia in 2012. This virus, called Middle East respiratory syndrome-coronavirus (MERS$\mathrm{CoV}$ ), spread to nearly 27 countries to date, affecting more than 2000 people, and the mortality rate was announced as 35\% (Zaki et al. 2012; de Groot et al. 2013).

In December 2019, SARS-CoV-2, also known as Corona-virus disease 2019 (COVID-19), which has emerged in the city of Wuhan of Hubei province in China and rapidly spread to China, has been identified (Guan et al. 2020). This event, which has turned into a pandemic as of March 11, 2020, has been declared as a global human health threat by the world health organization (WHO). As of April 19, 2020, it has been reported that 2.246.291 people have been affected and 152.707 people have been killed, spreading to 202 countries according to the WHO data (World health organization 2020). The virus starts with mild symptoms such as elevated fever, cough and difficulty in breathing and leads to the development of pneumonia. Based on symptoms, COVID-19 infection can be divided into three sickness table as an asymptomatic incubation period with or without detectable virus, non-severe symptomatic period with the presence of virus and, severe respiratory symptomatic stage with high viral load (Wang et al. 2020). Despite the ongoing drug research recently, there is still no definitive treatment for COVID-19.

The most common symptoms of CoVs infections in humans start with elevated fever $\left(>38{ }^{\circ} \mathrm{C}\right)$, followed by trembling, sore throat, cough, muscle pain, pneumonia, diarrhea (10-20\%), shortened depth of breathing or difficult breathing. The disease can be subclinical in some people, while it may be severe and fatal in those with weakened immune system, diabetes, hypertension, chronic liver disease, chronic obstructive pulmonary disease and heart disease, and in elderly patients (Guan et al. 2020; Al-Hazmi 2016; Cheng et al. 2007; Qin et al. 2020). The biggest question to be explained here is why some cases have the disease clinically severe, while others do not. Although we cannot exactly answer the problem by looking at the immune responses developed by patients infected with SARS-CoV, MERS-CoV or SARS-CoV-2, the immune responses of those with mild disease or resistance will not be sufficient to fully explain the wide spectrum of the disease, but will help us see the big picture.

\section{Immune Responses Induced by CoVs Infections}

The clinical manifestation indicates that acute lung injury is the main clinical characteristic of CoVs infections. The viral infection is a multifactorial pathophysiological process including cytokines, chemokines, inflammatory and immune cells (Table 1).

\section{SARS-COV}

When CoVs bind to certain cell surface molecules, the viral genome enters the host cell and infects the cells. How these molecules such as angiotensin-converting enzyme 2 (ACE2), carcinoembryonic-antigen-related cell-adhesion molecule-1 (CEACAM1), aminopeptidase $\mathrm{N}$ (APN) and dipeptidyl peptidase-4 (DPP-4), which are selected as the gate, are selected by 


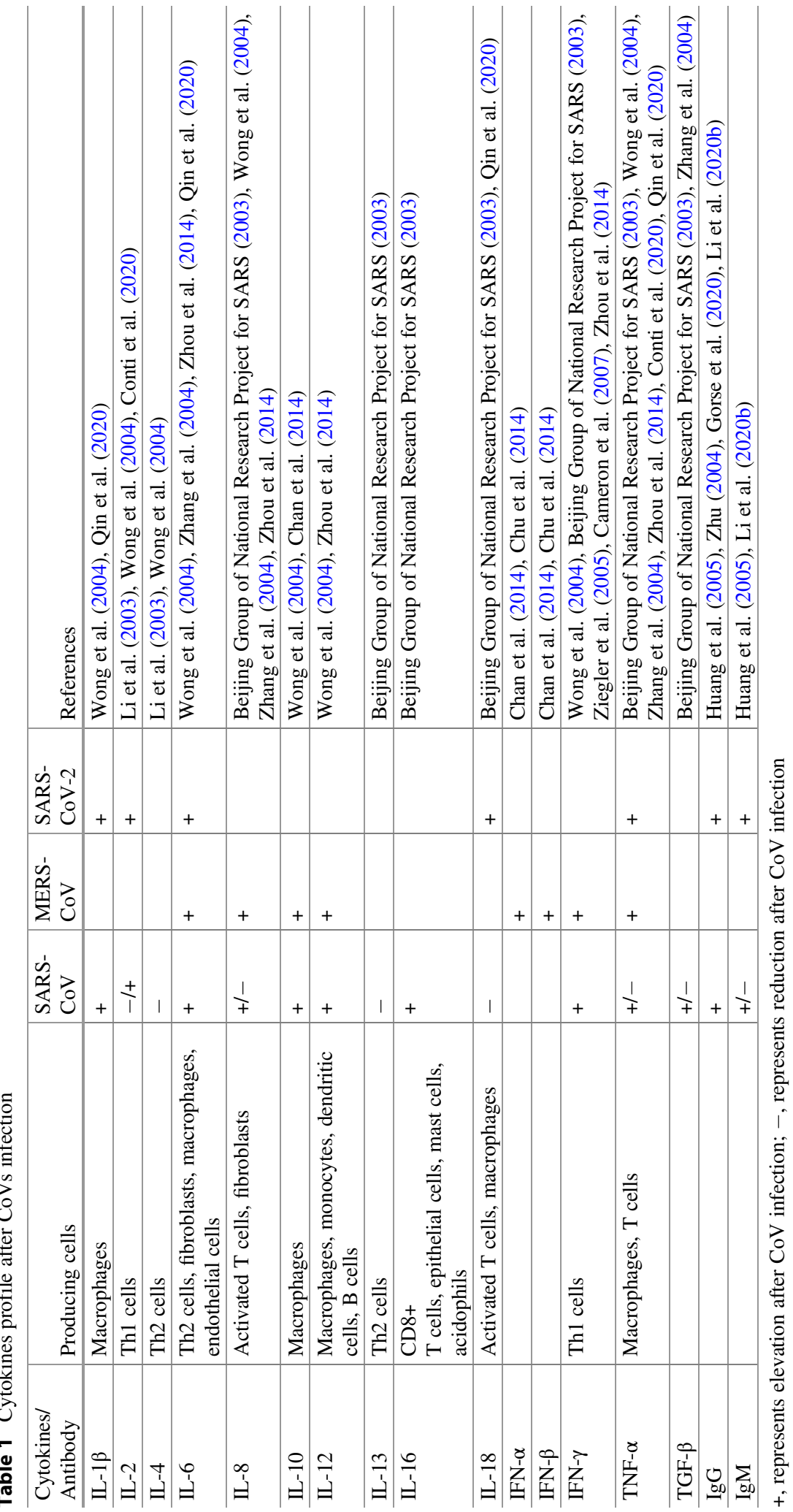


the virus is still uncertain ( $\mathrm{Li}$ 2015). SARS-CoV, which enters the cell through the ACE2 receptor, begins the transcription of the viral genome and the production of viral proteins. Meanwhile, the host defense system is stimulated. The virus directly infects macrophages and T-cells. The depletion of lymphopenia, thrombocytopenia, $\mathrm{T}$ helper $(\mathrm{CD} 4+)$ and cytotoxic $\mathrm{T}$ lymphocytes $(\mathrm{CD} 8+)$ in most of infected patients reflect the severity of the virus-related infection (Wong et al. 2003). Considering the cytokine pattern, which plays a significant role in determining the outcome of the disease, the cytokine interferon gamma (IFN- $\gamma$ ), which is produced by $\mathrm{T}$ cells and natural killer (NK) cells as a result of an immune response, increases significantly within 3-10 days. In contrast, another cytokine interleukin-4 (IL-4), which supports the immunity, decreases. IL-10, which inhibits the production of IFN- $\gamma$ by Th1 cells and the cytokine production in activated macrophages and shifts the immune response to $\mathrm{Th} 2$, also increases (Wong et al. 2003; Beijing Group of National Research Project for SARS 2003). Some studies conducted after SARS-CoV infection reported increased IL-2 levels ( $\mathrm{Li}$ et al. 2003), while others argued that it decreased (Wong et al. 2004). The concentrations of IL-1 $\beta$, IL- 6 and IL-12 also increase in the first 5-12 days after the onset of the disease (Wong et al. 2004). Since IL-12 is the maturation factor of $\mathrm{CD}^{+} \mathrm{T}$ cells and NK cells, it can induce the production of IFN- $\gamma$ and Th1 cytokines. IL- $1 \beta$ responds as an initial acting cytokine by performing the synthesis of acute phase proteins and the release of IL-8 against infection caused by the virus (Mogensen and Paludan 2001). And naturally, SARS-CoV-infected patients have an increase in chemokine IL-8 levels responsible for neutrophil activation in plasma along with monocyte chemoattractant protein-1 (MCP-1 or CCL2: C-C motif chemokine ligand 2) and human interferon-inducible protein 10 (IP-10 or CXCL10) levels within the first 14 days (Wong et al. 2004). It is known that IL-8 sometimes decreases with tumor growth factor beta (TGF- $\beta$ ), another cytokine that inhibits the proliferation of $\mathrm{T}$ cells and macrophage activation during viral infection (Zhang et al. 2004). Similarly, the level of tumor necrosis factor alpha (TNF- $\alpha$ ), which affects the hypothalamus for fever formation and facilitates acute phase protein production, has been found to elevate, while sometimes no change has been found (Zhang et al. 2004). Therefore, early elevation of inflammatory cytokines IFN- $\gamma$, IL- $1 \beta$, IL- 6 and IL-12 may cause activation of SAR1-CoV-induced Th1 cells and NK cells and release of chemokines such as IL-8, and the picture may result in pulmonary inflammation (Van Reeth et al. 2002). Strong chemo-attraction of chemokines such as macrophage inflammatory protein-1 alpha (MIP-l $\alpha$ or CCL3: C-C motif chemokine ligand 3), MCP-1 and IP-10, monocytes/macrophages, T cells and NK cells to the infection site is also notable. IL-8 also shows strong chemotaxis for neutrophils and other granulocytes (Zhou et al. 2014). While it has been emphasized in some studies that antiviral IFNs and cytokines are not stimulated in SARSCoV-infected macrophages and dendritic cells (Ziegler et al. 2005), other study groups have shown higher levels of IFN- $\gamma$ and IFN-stimulated genes (ISGs) in individuals with fatal SARS than individuals with mild to moderate SARS in addition to inflammatory cytokines and chemokines (Cameron et al. 2007; Huang et al. 2005). These data are the results suggesting a better investigation of the potential roles of IFNs and ISGs in the immunopathogenesis of SARS.

Chemokine IL-8, IP-10 and MCP-1 values are known to reach normal levels within 5-10 days after corticosteroid therapy,; however, no decrease occurs in IL-1- $\beta$, IL-6, IL-10, IL-12, TNF- $\alpha$ and IFN- $\gamma$ values (Wong et al. 2004; Zhang et al. 2004). Antibody levels of recovering patients showed that IgG persists for 13 weeks in all patients, but the $\operatorname{IgM}$ can be measured in a short time is as evidence that the $\mathrm{IgG}$ antibody expresses a primary humoral immune response to protect the patient against the virus. The reason for such high level of response is thought to be against the virus-specific spike (S) protein and nucleocapsid (N) protein (Zhu 2004). 


\section{4}

\section{MERS-CoV}

While SARS-CoV and SARS-CoV-2 use ACE2 as cell entry receptor, MERS-CoV uses DPP-4 as a specific receptor (Li 2015). DPP4 is a type-II transmembrane glycoprotein which is widely expressed on bronchial epithelium and macrophages. Therefore, human respiratory epithelial cells are highly susceptible to MERS-CoV infection. While the virus replicates in macrophages and dendritic cells (DC), it induces the production of pro-inflammatory cytokines. Infection of human $\mathrm{T}$ cells with MERS-CoV induces both intrinsic and extrinsic apoptotic pathways, causing the suppression of immune responses (Chan et al. 2014). This is the opposite picture of SARS-CoV, which infects monocyte-macrophages, DC and T cells to a lesser extent. Leukopenia and lymphopenia are also observed to a lesser extent in MERS patients than in SARS patients. TNF- $\alpha$, IL- 6 , IFN- $\gamma$ and IL-12 production is induced from MERS-CoVinfected macrophages and a series of antiviral responses begin. The production of chemokines such as IFN- $\lambda$ and CXCL10, CCL2, CCL3 and IL-8 also increases from DC or macrophages (Zhou et al. 2014). In addition, the stimulation of IFN- $\alpha$ and IFN- $\beta$ (type I interferons) expression from infected DC causes the release of chemokines such as MCP-1, CXCL10, and cytokines such as IL-10. The data emphasize that MCP-1, MIP-1 $\alpha$ and IL- 8 chemokines and the cytokine IL-12 are expressed higher in MERS-CoV infection compared to SARS-CoV infection (Zhou et al. 2014; Chu et al. 2014; Cheung et al. 2005).

Immune cell receptor chemokines and immune-stimulating cytokines have been induced to a significantly higher extent and for a long time in MERS-CoV infection compared to SARS-CoV (Zhou et al. 2014; Chu et al. 2014; Cheung et al. 2005). Therefore, it may be thought that the immunopathogenesis can be intensified in MERS, causing more severe diseases and higher deaths. The determination of cytokine/chemokine profiles with microarray-based analysis will more clearly demonstrate the immune responses between MERS-CoV and SARS-CoV infections. In addition to immune response findings, the genetic structure and pathogenic characteristics of the virus cannot be ignored for antiviral therapy.

\section{SARS CoV-2}

Worldwide data about SARS-CoV-2 declare the incubation period is about 3-7 days. Within the cases approximately $80 \%$ of infections are mild or asymptomatic, $15 \%$ needs oxygen support as severe cases, and 5\% are requiring ventilation in intensive care units (ICU) (Huang et al. 2020). SARS-CoV-2 use ACE2 to infect mostly human type I and type II pneumocytes and alveolar macrophages (Chu et al. 2020). The replication time of SARS-CoV-2 is 3.20 folds higher compared to SARS-CoV within $48 \mathrm{~h}$. By this way it became more infectious and infects more tissues in certain time (Chu et al. 2020). Recent studies showed the importance of both humoral and cellular immune response in protection to COVID19. The success of the SARS-CoV-2 to overcome the innate immune response, downregulate the IFNs and control the proinflammatory cytokine storm is still in debate ( $\mathrm{Li}$ et al. 2020a).

SARS-CoV-2 is in tendency to infect all areas of respiratory track and induce the production of IL-1 and IL-6 (Fig. 1). These mostly cause to lung inflammation, fever, fibrosis and finally result with pnemonia. Other proinflammatory cytokines as IL-2, IL-7, TNF- $\alpha$, Granulocyte colony stimulating factor (G-CSF), IP-10, MCP-1, MCP-1A are also responsible for cytokine storm and leads to cytokine release syndrome (CRS) in severe conditions (Conti et al. 2020). COVID-19 patients' data showed elevated inflammatory cytokines as IL- 6 , TNF- $\alpha$, IL-1, IL-2R and chemokines as IL-18 found in mostly severe COVID-19 cases (Qin et al. 2020). Further, increased C-reactive protein (CRP) levels with neutrophilia and lymphocytopenia, higher infection-related biomarker as procalcitonin, serum ferritin are harnessed with disease severity and mortality (Qin et al. 2020; Jiang et al. 2020). Both innate and adaptive immune outputs are responsible for sanatory immune-mediated health 


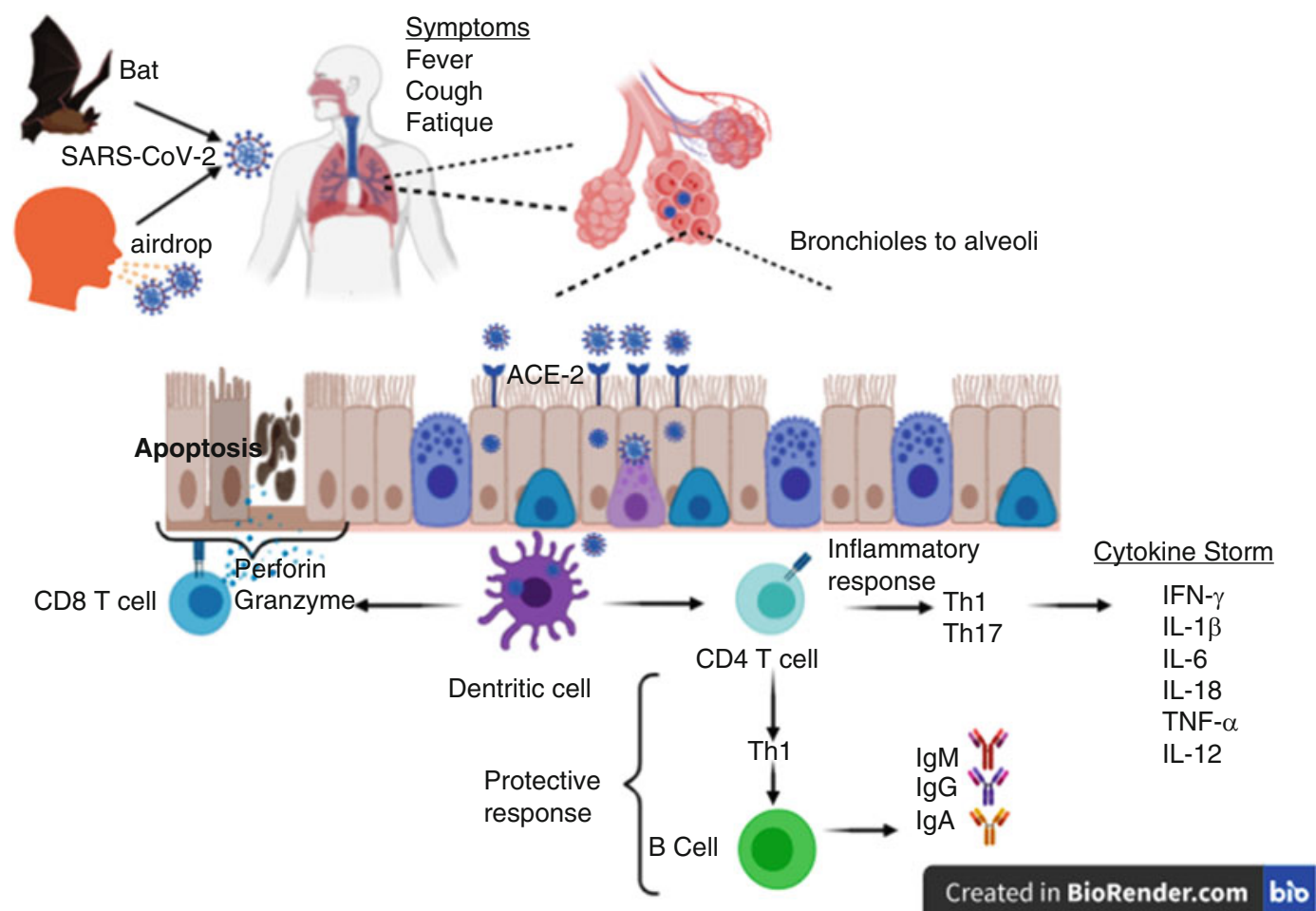

Fig. 1 İmmune response to SARS-CoV-2 Immune response to SARS-CoV-2. SARS-CoV2 spread out by airway and infect mostly airway bronchioles. Dendritic cells present viral antigen to $\mathrm{CD} 4^{+} \mathrm{T}$ cells and further cytkine storm starts in severe cases. Humoral immune

status. Premature results of COVID-19 patients revealed impaired lymphocyte numbers as an indicator of severe inflammation. Indeed, the ratios of naïve helper $\mathrm{T}$ cells to memory helper $\mathrm{T}$ cells are found to be increased in severe COVID-19 cases. And also decreased $\mathrm{CD}^{+} \mathrm{CD} 4^{+} \mathrm{CD} 45 \mathrm{RA}^{+}$naïve $\mathrm{T}$ cells and $\mathrm{CD} 3^{+} \mathrm{CD} 8^{+} \mathrm{CD} 28^{+}$cytotoxic suppressor $T$ cells can be associated with weakness of immune response to SARS-CoV-2 (Qin et al. 2020). Cellular immune system is activated with $\mathrm{T}$ cell response. Mostly for viral infections antigen specific $\mathrm{T}$ cells are produced and target to virally infected cells. In SARS-CoV-2 infections $\mathrm{CD}^{+} \mathrm{T}$ cell response is important to kill virally infected cells (Li et al. 2020a). We do not have enough data whether established immune response to SARSCoV-2 has a long continued memory.

In viral infections IgM forms the first response and then high affinity IgG production leads to response enhance the production of $\operatorname{IgG}, \operatorname{IgM}$ and $\operatorname{IgA}$ and viral entrance to other cells is prevented. $\mathrm{CD} 8^{+} \mathrm{T}$ cells secrete perforin and granzyme to kill virally infected cells

long term immunity (Racine and Winslow 2009). Virus neutralization is essential to stop spread of virus throughout the body tissues. Humoral immune response to SARS-CoV2 develops within week and neutralizing $\mathrm{IgG}$ antibodies that specific to $\mathrm{N}$ protein elevated in 14 days. Those patients became seropositive to the virus and negative for SARS-CoV-2 PCR in 28 days (Gorse et al. 2020). Rapid screening of SARS-CoV-2 IgM and IgG is important to early catch both symptomatic and asymptomatic carriers to diagnosis and treatment of COVID-19 disease ( $\mathrm{Li}$ et al. 2020b).

\section{Conclusion}

New clinical and laboratory data accrue every day from different centers of the world. Even we need 
more prospective and long term data in order to understand virus and claims incurred, on hand data draw almost picture. The superiority of SARS-CoV-2 to other Corona virus family is its incremental growth and high spread ability between people. Immunologic results showed impaired naïve and memory CD4 $+\mathrm{T}$ cell ratio, increased proinflammatory cytokine levels and cytokine storm result in need of intensive care support to patients. Recent therapeutic approaches still struggle with virus itself and cytokine storm. Vaccine based researches are still ongoing but it is no doubt that we need more time to induce the active immunity with vaccination. Further, mesenchymal stem cell based cellular therapy is important to prevent permanent damage of lung and quench cytokine storm. Although we need more time to understand the viral behavior, vaccine development and therapeutics, we are not fall behind.

\section{References}

Al-Hazmi A (2016) Challenges presented by MERS corona virus, and SARS corona virus to global health. Saudi J Biol Sci 23(4):507-511. https://doi.org/10. 1016/j.sjbs.2016.02.019

Beijing Group of National Research Project for SARS (2003) Dynamic changes in blood cytokine levels as clinical indicators in severe acute respiratory syndrome. Chin Med J 116(9):1283-1287

Cameron MJ, Ran L, Xu L, Danesh A, Bermejo-Martin JF, Cameron CM, Muller MP, Gold WL, Richardson SE, Poutanen SM, Willey BM, DeVries ME, Fang Y, Seneviratne C, Bosinger SE, Persad D, Wilkinson P, Greller LD, Somogyi R, Humar A et al (2007) Interferon-mediated immunopathological events are associated with atypical innate and adaptive immune responses in patients with severe acute respiratory syndrome. J Virol 81(16):8692-8706. https://doi.org/10. 1128/JVI.00527-07

Chan RW, Hemida MG, Kayali G, Chu DK, Poon LL, Alnaeem A, Ali MA, Tao KP, Ng HY, Chan MC, Guan Y, Nicholls JM, Peiris JS (2014) Tropism and replication of Middle East respiratory syndrome coronavirus from dromedary camels in the human respiratory tract: an in-vitro and ex-vivo study. Lancet Respir Med 2(10):813-822. https://doi.org/10.1016/S22132600(14)70158-4

Cheng VC, Lau SK, Woo PC, Yuen KY (2007) Severe acute respiratory syndrome coronavirus as an agent of emerging and reemerging infection. Clin Microbiol
Rev 20(4):660-694. https://doi.org/10.1128/CMR. 00023-07

Cheung CY, Poon LL, Ng IH, Luk W, Sia SF, Wu MH, Chan KH, Yuen KY, Gordon S, Guan Y, Peiris JS (2005) Cytokine responses in severe acute respiratory syndrome coronavirus-infected macrophages in vitro: possible relevance to pathogenesis. J Virol 79 (12):7819-7826. https://doi.org/10.1128/JVI.79.12. 7819-7826.2005

Chu H, Zhou J, Wong BH, Li C, Cheng ZS, Lin X, Poon VK, Sun T, Lau CC, Chan JF, To KK, Chan KH, Lu L, Zheng BJ, Yuen KY (2014) Productive replication of Middle East respiratory syndrome coronavirus in monocyte-derived dendritic cells modulates innate immune response. Virology 454-455:197-205. https://doi.org/10.1016/j.virol.2014.02.018

Chu H, Chan JF, Wang Y, Yuen TT, Chai Y, Hou Y, Shuai H, Yang D, Hu B, Huang X, Zhang X, Cai JP, Zhou J, Yuan S, Kok KH, To KK, Chan IH, Zhang AJ, Sit KY, Au WK, ... Yuen KY (2020) Comparative replication and immune activation profiles of SARSCoV-2 and SARS-CoV in human lungs: an ex vivo study with implications for the pathogenesis of COVID-19. Clin Infect Dis, ciaa410. https://doi.org/ 10.1093/cid/ciaa410. Advance online publication

Conti P, Ronconi G, Caraffa A, Gallenga CE, Ross R, Frydas I, Kritas SK (2020) Induction of pro-inflammatory cytokines (IL-1 and IL-6) and lung inflammation by Coronavirus-19 (COVI-19 or SARSCoV-2): anti-inflammatory strategies. J Biol Regul Homeost Agents 34(2):1. https://doi.org/10.23812/ CONTI-E. Advance online publication

de Groot RJ, Baker SC, Baric RS, Brown CS, Drosten C, Enjuanes L, Fouchier RA, Galiano M, Gorbalenya AE, Memish ZA, Perlman S, Poon LL, Snijder EJ, Stephens GM, Woo PC, Zaki AM, Zambon M, Ziebuhr J (2013) Middle East respiratory syndrome coronavirus (MERS-CoV): announcement of the Coronavirus Study Group. J Virol 87(14):7790-7792. https://doi.org/10.1128/JVI.01244-13

Gorse GJ, Donovan MM, Patel GB (2020) Antibodies to coronaviruses are higher in older compared with younger adults and binding antibodies are more sensitive than neutralizing antibodies in identifying coronavirusassociated illnesses. J Med Virol 92(5):512-517. https://doi.org/10.1002/jmv.25715

Guan WJ, Ni ZY, Hu Y, Liang WH, Ou CQ, He JX, Liu L, Shan H, Lei CL, Hui D, Du B, Li LJ, Zeng G, Yuen KY, Chen RC, Tang CL, Wang T, Chen PY, Xiang J, Li SY, ... China Medical Treatment Expert Group for Covid-19 (2020) Clinical characteristics of coronavirus disease 2019 in China. N Engl J Med. https://doi.org/ 10.1056/NEJMoa2002032. Advance online publication

Huang KJ, Su IJ, Theron M, Wu YC, Lai SK, Liu CC, Lei HY (2005) An interferon-gamma-related cytokine storm in SARS patients. J Med Virol 75(2):185-194. https://doi.org/10.1002/jmv.20255 
Huang C, Wang Y, Li X, Ren L, Zhao J, Hu Y, Zhang L, Fan G, Xu J, Gu X, Cheng Z, Yu T, Xia J, Wei Y, Wu W, Xie X, Yin W, Li H, Liu M, Xiao Y, ... Cao B (2020) Clinical features of patients infected with 2019 novel coronavirus in Wuhan, China. Lancet (London, England) 395(10223):497-506. https://doi.org/10. 1016/S0140-6736(20)30183-5

Jiang F, Deng L, Zhang L, Cai Y, Cheung CW, Xia Z (2020) Review of the clinical characteristics of coronavirus disease 2019 (COVID-19). J Gen Intern Med. https://doi.org/10.1007/s11606-020-05762-w. Advance online publication

Li F (2015) Receptor recognition mechanisms of coronaviruses: a decade of structural studies. J Virol 89 (4):1954-1964. https://doi.org/10.1128/JVI.02615-14

Li Z, Guo X, Hao W, Wu Y, Ji Y, Zhao Y, Liu F, Xie X (2003) The relationship between serum interleukins and T-lymphocyte subsets in patients with severe acute respiratory syndrome. Chin Med J 116 (7):981-984

Li G, Fan Y, Lai Y, Han T, Li Z, Zhou P, Pan P, Wang W, Hu D, Liu X, Zhang Q, Wu J (2020a) Coronavirus infections and immune responses. J Med Virol 92 (4):424-432. https://doi.org/10.1002/jmv.25685

Li Z, Yi Y, Luo X, Xiong N, Liu Y, Li S, Sun R, Wang Y, Hu B, Chen W, Zhang Y, Wang J, Huang B, Lin Y, Yang J, Cai W, Wang X, Cheng J, Chen Z, Sun K, ... Ye F (2020b) Development and clinical application of a rapid IgM-IgG combined antibody test for SARSCoV-2 infection diagnosis. J Med Virol. https://doi. org/10.1002/jmv.25727. Advance online publication

Mogensen TH, Paludan SR (2001) Molecular pathways in virus-induced cytokine production. Microbiol Mol Biol Rev 65(1):131-150. https://doi.org/10.1128/ MMBR.65.1.131-150.2001

Peiris JS, Yuen KY, Osterhaus AD, Stöhr K (2003) The severe acute respiratory syndrome. N Engl J Med 349 (25):2431-2441. https://doi.org/10.1056/NEJMra032498

Qin C, Zhou L, Hu Z, Zhang S, Yang S, Tao Y, Xie C, Ma K, Shang K, Wang W, Tian DS (2020) Dysregulation of immune response in patients with COVID-19 in Wuhan, China. Clin Infect Dis, ciaa248. https://doi.org/10.1093/cid/ciaa248. Advance online publication

Racine R, Winslow GM (2009) IgM in microbial infections: taken for granted? Immunol Lett 125 (2):79-85. https://doi.org/10.1016/j.imlet.2009.06.003

Van Reeth K, Van Gucht S, Pensaert M (2002) In vivo studies on cytokine involvement during acute viral respiratory disease of swine: troublesome but rewarding. Vet Immunol Immunopathol 87(3-4):161-168. https://doi.org/10.1016/s0165-2427(02)00047-8

Wang D, Hu B, Hu C, Zhu F, Liu X, Zhang J, Wang B, Xiang H, Cheng Z, Xiong Y, Zhao Y, Li Y, Wang X, Peng Z (2020) Clinical characteristics of 138 hospitalized patients with 2019 novel coronavirus-infected pneumonia in Wuhan, China. JAMA, e201585. https://doi.org/10. 1001/jama.2020.1585. Advance online publication
Wong RS, Wu A, To KF, Lee N, Lam CW, Wong CK, Chan PK, Ng MH, Yu LM, Hui DS, Tam JS, Cheng G, Sung JJ (2003) Haematological manifestations in patients with severe acute respiratory syndrome: retrospective analysis. BMJ (Clin Res Ed) 326(7403):1358-1362. https://doi. org/10.1136/bmj.326.7403.1358

Wong CK, Lam CW, Wu AK, Ip WK, Lee NL, Chan IH, Lit LC, Hui DS, Chan MH, Chung SS, Sung JJ (2004) Plasma inflammatory cytokines and chemokines in severe acute respiratory syndrome. Clin Exp Immunol 136(1):95-103. https://doi.org/10.1111/j.1365-2249. 2004.02415.x

Woo PC, Lau SK, Huang Y, Yuen KY (2009) Coronavirus diversity, phylogeny and interspecies jumping. Exp Biol Med (Maywood, N.J.) 234(10):1117-1127. https://doi.org/10.3181/0903-MR-94

Woo PC, Lau SK, Lam CS, Lau CC, Tsang AK, Lau JH, Bai R, Teng JL, Tsang CC, Wang M, Zheng BJ, Chan KH, Yuen KY (2012) Discovery of seven novel Mammalian and avian coronaviruses in the genus deltacoronavirus supports bat coronaviruses as the gene source of alphacoronavirus and betacoronavirus and avian coronaviruses as the gene source of gammacoronavirus and deltacoronavirus. J Virol 86(7):3995-4008. https:// doi.org/10.1128/JVI.06540-11

World health organization, Coronavirus disease (COVID-2019) outbreak situation. https://www.who.int/ emergencies/diseases/novel-coronavirus-2019. Accessed 20 Apr 2020

Zaki AM, van Boheemen S, Bestebroer TM, Osterhaus AD, Fouchier RA (2012) Isolation of a novel coronavirus from a man with pneumonia in Saudi Arabia. N Engl J Med 367(19):1814-1820. https://doi.org/10. 1056/NEJMoa1211721

Zhang Y, Li J, Zhan Y, Wu L, Yu X, Zhang W, Ye L, Xu S, Sun R, Wang Y, Lou J (2004) Analysis of serum cytokines in patients with severe acute respiratory syndrome. Infect Immun 72(8):4410-4415. https://doi. org/10.1128/IAI.72.8.4410-4415.2004

Zhou J, Chu H, Li C, Wong BH, Cheng ZS, Poon VK, Sun T, Lau CC, Wong KK, Chan JY, Chan JF, To KK, Chan KH, Zheng BJ, Yuen KY (2014) Active replication of Middle East respiratory syndrome coronavirus and aberrant induction of inflammatory cytokines and chemokines in human macrophages: implications for pathogenesis. J Infect Dis 209(9):1331-1342. https:// doi.org/10.1093/infdis/jit504

Zhu M (2004) SARS immunity and vaccination. Cell Mol Immunol 1(3):193-198

Ziegler T, Matikainen S, Rönkkö E, Osterlund P, Sillanpää M, Sirén J, Fagerlund R, Immonen M, Melén K, Julkunen I (2005) Severe acute respiratory syndrome coronavirus fails to activate cytokinemediated innate immune responses in cultured human monocyte-derived dendritic cells. J Virol 79 (21):13800-13805. https://doi.org/10.1128/JVI.79.21. 13800-13805.2005 